\title{
The Actualization of the Malaysian National Education Philosophy in Secondary Schools: Student and Teacher Perspectives
}

\author{
Shafeeq Hussain Vazhathodi Al-Hudawi ${ }^{1}$, Rosy Lai Su Fong ${ }^{1}$, Mohammed Borhandden Musah ${ }^{1} \&$ Lokman \\ Mohd Tahir ${ }^{1}$ \\ ${ }^{1}$ Faculty of Education, Universiti Teknologi Malaysia, Malaysia \\ Correspondence: Shafeeq Hussain Vazhathodi Al-Hudawi, Department of Educational Foundation and Social \\ Science Studies, Faculty of Education, Universiti Teknologi Malaysia, UTM Johor Bahru 81310, Johor, \\ Malaysia. Tel: 607-553-3177. E-mail: shafeeq@utm.my; shafeeq75@gmail.com
}

Received: January 14, 2014 Accepted: February 25, 2014 Online Published: March 25, 2014

doi:10.5539/ies.v7n4p57

URL: http://dx.doi.org/10.5539/ies.v7n4p57

\begin{abstract}
In the Malaysian context, all educational processes at the national level are envisioned by the National Education Philosophy (NEP). The NEP was formed in 1988 in line with the National Principles (Rukun Negara) with the ultimate aims of building a united and progressive society (Ministry of Education, 2001). However, there is uncertainty whether the NEP has been actualized in the educational processes, transmitted successfully by teachers to students and further personalized by students. This paper aims to report findings of study which analyzed the actualization of the NEP in government and private secondary schools based on student and teacher perspectives. The research followed a survey design through two sets of questionnaires; one for teachers and the other for students. The Cronbach's Alpha reliability coefficient value for the teacher and student questionnaire was 0.96 and 0.98 respectively. A total of 185 Form 4 students and 45 teachers from both private and government secondary schools in Kuching, Sarawak, Malaysia participated in this research. $77.3 \%$ of students and $64.4 \%$ of teachers rated the level of actualization of the NEP as high, with a mean score of 7.67 and 7.28 out of 10 as rated by the students and teachers respectively. The paper further discusses the finding of the study from both teacher and student perspectives. It also provides a brief discussion on the limitations of this study and on its implications. It concludes with general implications of the study to the educational processes in the country in general and to the national education system in specific.
\end{abstract}

Keywords: Malaysian national education philosophy, actualization, secondary schools

\section{Introduction}

A coherent vision is vital to any efforts that humans undertake. This is especially true to the educational efforts. A common educational vision, enshrined in the Philosophy of Education of a nation is like a lighthouse in providing guidelines and turning its educational efforts into success. However, it is undeniable that "bearing of philosophy on education is somewhat indirect, for most educators have to take the subject-matter to a large extent at second-hand, and have no time to inquire how far it is true, in any ultimate sense of the word" (Mackenzie, 1898, p. 428). Thus, as pointed out by Wilson (1977), the utmost important matter is how to integrate philosophy of education in curriculum and how to actualize the elements of philosophy in the educational processes.

As Lewy (1977) suggested, in order to find out whether students have mastered certain skills as a result of the educational programs and whether they have acquired certain desired attitudes and values, it is necessary that the curriculum, and even the general aims be evaluated in a continual process. The general aims are positions taken based on a set of beliefs on (i) What type of citizen we want to produce? (ii) What type of world or society we would love to live in? (iii) What are the values that we cherish?, and (iv) What are the logical relation between all these? Answers to these questions undeniably imply upon the educational efforts in any country, especially the schooling processes. As Peter (1997, p. 176) indicated, "statements of aims of education are positions taken based on a set of beliefs". Such statements are usually made through philosophical deliberations or philosophizing. Philosophical deliberations involve various ontological, metaphysical, epistemological, axiological, teleological and aesthetic discussions. The principles that underlie these deliberation and discussions-and thereby the all educational assumptions and practices-are very fundamental to formulating "the 
aims of education and the functions of educational institutions in a society" (Butler, 1968, p. 486).

Overall, thus, philosophy of education is the theory and ideology of education. It helps to shape educational principles, guidelines, assumptions and decisions with respect to learning and teaching, intellectual and moral building and education goal (Mohamed, 1990). This is very true about the Malaysian education context.

Malaysia has a long history of education system developments, from pre to post independence period. Therefore, Malaysian authorities had to deliberate a coherent philosophy of education accommodating for its multi-ethnic, religious, linguistic and cultural society, but based on the long tradition of Malay and Islamic based education and taking account of eastern and western philosophies brought by the influx of the Chinese and Indians to Malaysia (Sang, 2008; Nooraini \& Khairul, 2011). This was realized through the formation of the National Education Philosophy (NEP).

In the Malaysian context, all educational processes at the national level are envisioned by the NEP. For, example, even the latest Preliminary Report: Malaysia Education Blueprint 2013-2025 released on September 11, 2012 by the Ministry of Education reiterates the commitment of the Malaysian school curriculum to the National Education Philosophy. The Blueprint charts out strategic and operational pathways and shifts to transform the country's education system and assure to continue to use "the NEP's vision of a balanced education as its foundation for individual student aspirations" (p. E-16).

The NEP reads:

"Education in Malaysia is an on-going effort towards further developing the potential of individuals in a holistic and integrated manner, so as to produce individuals who are intellectually, spiritually, emotionally and physically balanced and harmonious based on a firm belief in and devotion to God. Such an effort is designed to produce Malaysian citizens who are knowledgeable and competent, who possess high moral standards and who are responsible and capable of achieving a high level of personal well-being as well as being able to contribute to the betterment of the family, society and the nation at large" (Ministry of Education, 2008, p. ix).

The National Education Philosophy (NEP) was officially formed in 1988 according to the needs of Malaysian citizens and the country, especially for the betterment of its citizens in line with the National Principles (Rukun Negara) with ultimate aims of building a united and progressive society (Ministry of Education, 2001).

The NEP was tailored in accordance with the needs of individual citizens, family, society in the country as a whole. The unity and betterment of its citizen was one of basic consideration of NEP (Sang, 2008). Six factors that were well recognized while forming of the NEP are religion, social fabrics, politics, economy, individuality and globalization (Meng, 1996). The religion factor takes multiple religions embraced by the people into the consideration, with Islam as the official religion of the country, yet freedom to embrace other religions also given. The social factor includes the multicultural structure of Malaysian society. The political factor determines ideology of the country and further influences education policy. The economic factor influences the educational goals in an effort to bringing development and progress to the country. The individual factor is related to basic needs such as security, development and execution of individual potential and self-actualization. The last factor of globalization is associated with global outlook and vision, the development of global education and the capability of Malaysian citizens to contribute to gain global recognition. Providing for and producing appropriate mix of human capital for all level of market needs as well as for racial harmonization and integration focusing on social welfare and economic prosperity as a whole are two essential concepts brought about by the NEP. Specifically the roles of NEP as accounted by Meng (1996) and Sang (2008) include:

(a) Provide guidance and direction to the efforts to expand and improve education;

(b) As basic policy and consideration for determining the national education goals;

(c) As a reference for educators (local or overseas) to understand the educational system in Malaysia;

(d) As a guidance for educators to perform educational tasks;

(e) As the basis and foundation for determining the curriculum, teaching materials and learning and teaching strategies;

(f) As controller on distortion of education policy activities and to eliminate misunderstandings, doubts or disputes while putting effort to perform educational tasks or activities;

(g) To avoid any inconvenience that may arise during implementation of a particular curriculum or its component;

(h) As basic considerations while planning for the reform or change in the education system. 
In short, the NEP was adopted in the culmination of a long search for "a national system of education to serve as the foundation for integrating various ethnic groups, as well as the agent for socioeconomic development..." (Rosnani, 2004, p. 113).

In general, the Ministry of Education (2001) Malaysia has categorized the elements of the NEP into fifteen (15) sub-groups as stated in the manual entitled "National Education Philosophy, Goal and Mission" (Falsafah Pendidikan Kebangsaan, Matlamat dan Misi). The sub-group includes: (a) education is an on-going effort, (b) developing the potential of individual, (c) develop the potential in a holistic and integrate manner, (d) a balanced and harmonious individual, (e) intellectual element, (f) spiritual element, (g) emotional element, (h) physical element, (i) firm belief in and devotion to God, (j) Malaysia citizens who are knowledgeable, (k) Malaysia citizens who are competent, (1) Malaysia citizens who possesses high moral standard, (m) Malaysia citizens who are responsible, (n) Malaysia citizens who are capable of achieving a high level of personal well-being, and (o) Malaysia citizens who are able to contribute to the betterment of the family, society and the nation. These elements are the key concepts that were studied in this study as to what extent they were actualized by students.

Put in different words, as indicated by Meng (1996) and Sang (2008) various changes made in the school curriculum are aligned with objectives of the NEP. For example the current KSSR (Kurikulum Standard Sekolah Rendah) [Curriculum Standard for Primary School], KBSR (Kurikulum Bersepadu Sekolah Rendah) [Malaysian National Primary School Syllabus] and KBSM (Kurikulum Bersepadu Sekolah Menengah) [Malaysian National Secondary School Syllabus] were aligned with the objectives of the NEP.

For example, according to Mohd, Abdul-Rahim, Ahmad-Johari, and Ali (2011) the implementation of the KBSM based on the concept of integrated education was an important step towards realizing the objectives of NEP. As instance, values embedded in teaching, learning styles as well as the usage of Malay language in KBSM are linked with the NEP (Mohd et al., 2011). Thus, according to them, "the Malaysian Education System entered a new and important phase with the creation of the National Education Philosophy" (p. 210).

\section{Statement of Research Problem}

The success rate for translating the NEP into educational process will increase as the conviction level on the NEP is on increase. Hence, the degree of conviction on the NEP is anticipated to attribute to the successful actualization of the NEP in students. This study, therefore analysed whether the NEP has been transmitted into the actual life of the secondary students as what has been intended by the Ministry of Education Malaysia.

Up to the best notice of the researchers, there are no researches that studied all elements of the NEP in secondary schools, especially with regards to all the fifteen elements in the sub-groups indicated above. A handful of researchers studied certain elements such as "the holistic development" (Habsah \& Aminuddin, 2009) and "firm belief in God" (Habsah et al., 2009). The latter qualitative study showed that 11 out of 12 secondary school teachers who teach different subjects at 5 different schools have firm belief in God though there are constraints to implying it in real teaching. One teacher who teaches a technical subject viewed that the belief in God having no relation with the subject he teaches. Another study by Rohana, Kamarudzaman, and Roziah (2010) developed a conceptual model for spiritual development based on the NEP. They studied how this specific spiritual development was implied in the delivery of teaching and learning process. Seng (2008) and Muhamad (1993) indicated that degree of understanding on the NEP among secondary school teachers in government school and vocational school respectively to be high, whereas appreciation toward the NEP was moderate. Thus, the level of actualization of the NEP among students has remained vague.

However, no quantitative studies were carried out to investigate the actualization of NEP among secondary school students and teachers. This study, therefore was conducted in order to analyze whether students who have undergone schooling at the secondary level have internalized the elements of the NEP as identified above, and what teachers themselves perceive about their students internalizing them. The overall purpose of the study, therefore, was to analyze the actualization of the NEP in government and private secondary school based on student and teacher perspectives. The study also aimed to identify differences between student and teacher perspectives on the actualization of the NEP in secondary school students and between government and private secondary schools. As such, the study hypothesizes:

Hypothesis 1: There is no difference between student and teacher perspectives for the actualization of the NEP in secondary school students.

Hypothesis 2: There is no difference between the level of the actualization for the NEP in government secondary school students and the level of actualization for the NEP in private secondary school students. 


\section{Methodology}

\subsection{Research Design}

The study utilized survey design for this research in view of its nature of inquiry on the trends of the actualization of the NEP among secondary school students. The design is preferred when a researcher seeks to describe trends in a large population of individuals, which is so in the case of this research (Creswell, 2012). Hence, data for this research was collected through two sets of questionnaires distributed among students and teachers in secondary schools.

In general, each set of questionnaire is divided into three sections, Section A: Background information on respondents, Section B: Knowledge and appreciation towards the NEP, Section C student and teacher perspectives.

Section A served to provide background of the respondents, whereas Section B was used to understand basic knowledge on and the level of appreciation of students and teachers about the NEP. The Section C was designed to obtain data to achieve the main objective of this research, which is to analyse the actualization of the NEP in government and private secondary school. The statements in the NEP were divided into fifteen sub-groups in accordance to the elaboration provided in the handbook of Ministry of Education and then further broken down into eighty five (85) statements as present in below:

(1) Education is an on-going effort (Question 1-3).

(2) Developing the potential of individual (Question 4-8).

(3) Potential development in a holistic and integrate manner (Question 9-11).

(4) A balanced and harmonious individual (Question 12-20).

(5) Intellectual element (Question 21-29).

(6) Spiritual element (Question 30-36).

(7) Emotional element (Question 37-42).

(8) Physical element (Question 43-48).

(9) Firm belief in and devotion to God (Question 49-55).

(10) Malaysian citizens who are knowledgeable (Question 56-58).

(11) Malaysian citizens who are competent (Question 59-62).

(12) Malaysian citizens who possess high moral standard (Question 63-67).

(13) Malaysian citizens who are responsible (Question 68-73).

(14) Malaysian citizens who are capable of achieving a high level of personal well-being (Question 74-76).

(15) Malaysian citizens who are able contribute to the betterment of the family, society and the nation (Question 77-85).

Each question was modified by adding personal pronoun, so that students and teachers were able to understand and make logical sense of the statements. Students were required to rate each question from 0 (not having the element at all) to 10 (with full confidence that he/she possesses the prescribed element). All the subject teachers of the students (respondents) were also requested to rate their students' actualization of fifteen elements of the NEP from 0 to 10, thereby to investigate whether there is any difference between teacher and student perspectives. A ratio scale is adopted instead of the commonly used Likert scale, anticipating more adequate and in-depth rating than just merely asking the level of agreement to identify the actualization of the NEP. The similar ratio scale also has been used by Lewy (1978) to rate the level of performance in curriculum evaluation. The questionnaires were pilot tested with a Cronbach's Alpha reliability coefficient value of 0.96 and 0.98 respectively for teacher and student instruments.

Stratified sampling method was adopted as the sample is stratified on some specific characteristics as tabulated in Table 1. This sampling method involves division (stratification) of the population on some specific characteristics and then using simple random sampling to guarantee the sample will include specific characteristics required in the research (Creswell, 2012). As to ensure the sample is representative of the population, two different types of school are selected, government secondary schools and private secondary schools. 
Table 1 . Selection criteria for secondary school

\begin{tabular}{|c|c|}
\hline Name of Schools & Selection Criteria \\
\hline \multicolumn{2}{|c|}{ Government Secondary School } \\
\hline SM Sains Kuching & $\begin{array}{l}\text { Full residential school with excellent academic } \\
\text { result, } 100 \% \text { passing in SPM (Zoee, 2011) }\end{array}$ \\
\hline SMK St. Joseph & $\begin{array}{l}\text { Public school established for more than } 100 \text { years } \\
\text { (boy's school) }\end{array}$ \\
\hline SMK Tabuan Jaya & New sports school in Kuching \\
\hline \multicolumn{2}{|c|}{ Private Secondary School } \\
\hline Chung Hua Middle School No.1 & $\begin{array}{l}\text { Independent Chinese middle school using Dong } \\
\text { Xia curricula }\end{array}$ \\
\hline Sunny Hill School & Religious school using national curricula \\
\hline
\end{tabular}

After schools have been determined, the sample size of students was designated by adopting Sampling Error Formula created by Fowler (as cited in Creswell, 2012, p. 610). The Formula is suitable to be used when the actual amount of the population is unknown. Ministry of Education only published the total number of students in government secondary schools, with a total of 47,284 students as at 2011 (Ministry of Education Malaysia, 2011). However, the actual amount of Form 4 students is unknown. Besides, there is no published statistics on private secondary schools. Hence, Fowler's Sample Size Table was used in view that the information about the population size was limited.

With $95 \%$ confidence interval, low sampling error rate of $4 \%$ (Creswell, 2012) and $10 \%$ chances to participate in this study; the Sampling Error Formula indicated the suitable sample size was 200 student respondents. As for teacher, the sample size was all the subject teachers who teach the student respondents. Overall, the collected sampling size for each school is presented in Table 2 .

Table 2. Distribution of respondents by schools

\begin{tabular}{lcccc}
\hline School & No. of Teacher & $\%$ & No. of Student & $\%$ \\
\hline Chung Hua Middle School No.3 & 4 & 8.8 & 42 & 22.7 \\
Sunny Hill Secondary School & 7 & 15.6 & 15 & 8.1 \\
SM Sains Kuching & 9 & 20.0 & 45 & 24.3 \\
SMK St Joseph & 18 & 40.0 & 56 & 30.3 \\
SMK Tabuan Jaya & 7 & 15.6 & 27 & 14.6 \\
Total & 45 & 100.0 & 185 & 100.0 \\
\hline
\end{tabular}

All data in this research were analyzed by using "Statistical Package for Social Sciences (SPSS). Section A and $B$ which comprised the background information on respondents and knowledge about the NEP respectively were analyzed by using descriptive approach, in the forms of frequency and percentage.

Data in Section $\mathrm{C}$ were analyzed according to the research objectives, which the level of actualization was categorized into low, moderate and high actualization by setting class interval.

$$
\text { Class Interval }=\frac{\text { Highest Value }- \text { Lowest Value }}{\text { Number of classes }}=\frac{10-0}{3}=3.33
$$

With a scale of $0-10$, the highest value is 10 whereas the lowest value is 0 . The numbers of interval classes were set to three, which comprised low, moderate and high actualization. With reference to the above formula, the width of class interval is rounded up to 3.3. Hence, the overall class interval is as presented in Table 3 . 
Table 3. Class interval for the level of actualization of the NEP

\begin{tabular}{cccc}
\hline $\begin{array}{c}\text { Class Interval } \\
\text { (mean scores) }\end{array}$ & Lower Real Limit & Upper Real Limit & $\begin{array}{c}\text { Level of Actualization of } \\
\text { the NEP }\end{array}$ \\
\hline $0 \leq \mathrm{x} \leq 3.3$ & 0.0 & 3.35 & Low actualization \\
$3.4 \leq \mathrm{x} \leq 6.7$ & 3.35 & 6.75 & Moderate actualization \\
$6.8 \leq \mathrm{x} \leq 10$ & 6.75 & 10.0 & High actualization \\
\hline
\end{tabular}

An Independent-measures t-test was used to test hypotheses $\mathrm{H}_{01}$ and $\mathrm{H}_{02}$. More specifically, the mean score of each questionnaire was used for hypothesis testing.

\section{Findings and Discussion}

Overall, the analysis yielded that $97.8 \%$ of teacher respondents who had already heard about the NEP say that they knew the content of the NEP. A total of $53.3 \%$ of teachers were very appreciative of the existing elements of the NEP, whereas $40 \%$ of them moderately appreciated the existing elements of the NEP. More than half $(52.2 \%)$ of the teacher respondents indicated that they were never trained to deliver the NEP. As for students, only $28.1 \%$ had ever heard about the NEP, $15.1 \%$ knew the general content of the NEP, and $12.4 \%$ knew the specific content of the NEP. Majority of the students (50.3\%) moderately appreciated the existing of the NEP.

\subsection{Level of Actualization of the NEP in Secondary Schools Based on Student Perspectives}

With reference to the results tabulated in Table 4, majority of the students (77.3\%) claimed that the level of actualization of the NEP was high in their lives, whereas $22.2 \%$ perceived the level of actualization was moderate as presented in Table 4 . Only $0.5 \%$ of students perceived the NEP had been lowly actualized.

Table 4. The level of actualization of the NEP in secondary schools based on student perspectives

\begin{tabular}{ccccccc}
\hline $\begin{array}{c}\text { Class Interval } \\
\text { (mean scores) }\end{array}$ & \multicolumn{2}{c}{ Private } & \multicolumn{2}{c}{ Government } & \multicolumn{2}{c}{ Total } \\
\hline $0 \leq \mathrm{x} \leq 3.3$ & 1 & 1.8 & 0 & 0 & 1 & 0.5 \\
$3.4 \leq \mathrm{x} \leq 6.7$ & 21 & 36.8 & 20 & 15.6 & 41 & 22.2 \\
$6.8 \leq \mathrm{x} \leq 10$ & 35 & 61.4 & 108 & 84.4 & 143 & 77.3 \\
Total & 57 & 100 & 128 & 100 & 185 & 100 \\
\hline
\end{tabular}

Overall, the mean score that rated by the students is 7.67 out of 10 . The details of data for each element are presented in Table 5. 
Table 5. Student perspectives on actualization of the NEP on students in private and government secondary schools

\begin{tabular}{llcccccc}
\hline \multirow{2}{*}{ Element of the NEP } & \multicolumn{3}{c}{ Private } & \multicolumn{3}{c}{ Government } \\
\cline { 5 - 7 } & mean & min & max & mean & min & max \\
\hline 1) & Education is an on-going effort & 6.88 & 0.00 & 10.0 & 7.43 & 0.67 & 10.0 \\
2) & Developing the potential of individual & 6.77 & 0.20 & 10.0 & 7.38 & 1.00 & 10.0 \\
3) & Develop the potential in a holistic and integrated & 7.15 & 1.67 & 10.0 & 7.63 & 3.00 & 10.0 \\
& manner & & & & & & \\
4) & A balanced and harmonious individual & 6.98 & 3.11 & 10.0 & 7.50 & 3.78 & 9.89 \\
5) & Intellectual element & 7.20 & 2.33 & 10.0 & 8.32 & 3.67 & 10.0 \\
6) & Spiritual element & 7.00 & 1.00 & 10.0 & 8.88 & 1.71 & 10.0 \\
7) & Emotional element & 7.41 & 2.17 & 10.0 & 7.84 & 3.00 & 10.0 \\
8) & Physical element & 7.06 & 1.33 & 10.0 & 7.18 & 2.33 & 10.0 \\
9) & Firm belief in and devotion to God & 6.85 & 2.43 & 10.0 & 8.82 & 0.43 & 10.0 \\
10) & Malaysian citizens who are knowledgeable & 7.23 & 0.00 & 10.0 & 7.58 & 0.00 & 10.0 \\
11) & Malaysian citizens who are competent & 7.23 & 0.00 & 10.0 & 7.55 & 1.75 & 10.0 \\
12) & Malaysian citizens who possess high moral & 7.76 & 2.60 & 10.0 & 8.37 & 3.00 & 10.0 \\
& standards & & & & & & \\
13) & Malaysian citizens who are responsible & 7.21 & 0.50 & 10.0 & 7.85 & 2.33 & 10.0 \\
14) & Malaysian citizens who are capable of achieving & 7.45 & 2.0 & 10.0 & 7.92 & 3.33 & 10.0 \\
& a high level of personal well-being & & & & & & \\
15) Malaysian citizens who are able to contribute to & 6.95 & 1.11 & 10.0 & 7.72 & 1.56 & 10.0 \\
& the betterment of the family, society and the & & & & & & \\
nation & & & & & & \\
\hline
\end{tabular}

With reference to Table 5, the perspective of students on the actualization of the NEP was quite similar between private and secondary schools, where students in both government and private schools claimed that the element "Malaysian citizens who possess high moral standards" was one of the top three elements possessed by them. 95.7\% of the students were Muslims, Christian and Buddhist; hence possessing high moral standard was anticipated. Pragmatic moral values are the heart of teaching of Buddhism, Christianity and Islam. Sang (2008) also indicated that education system in Malaysia is influenced by the western (Christianity), eastern (Confucianism) and Islamic philosophy.

From student perspectives, the elements least possessed by them were "Developing the potential of individual" and "Education is an on-going effort". In Malaysia, the national examination system and School-based Assessments or Pentaksiran Berasaskan Sekolah (PBS) mostly assesses the intellectual element of students and not emotional, spiritual and physical aspects. Therefore, the perspectives of students about absence of well-planned program to develop their potential were aligned with the current trend of education system in Malaysia. Habsah and Aminuddin (2009) indicated transmission of the NEP's core values across the curriculum are not evaluated in examinations. For "Education is an on-going effort", students in private schools perceived they were lacking in putting on-going effort in learning, whereas students in government secondary schools claimed that they lacked in updating themselves with the latest knowledge to accommodate with changes in the world. These results were advocated by Lee et al. (2011) where many learners face problems in self-managing their learning.

\subsection{Level of Actualization of the NEP in Secondary Schools Based on Teacher Perspectives}

The analysis revealed that majority of the teachers (64.4\%) proclaimed that the level of actualization of the NEP on their students was high, whereas $35.6 \%$ perceived the level of actualization was moderate. Furthermore, none of the teacher perceived the NEP was lowly actualized in their students. Table 6 depicts the details. 
Table 6 . The level of actualization of the NEP in secondary schools based on teacher perspectives

\begin{tabular}{ccccccc}
\hline $\begin{array}{c}\text { Class Interval } \\
\text { (mean scores) }\end{array}$ & \multicolumn{2}{c}{ Private } & \multicolumn{2}{c}{ Government } & \multicolumn{2}{c}{ Total } \\
\hline $0 \leq \mathrm{x} \leq 3.3$ & 0 & 0 & 0 & 0 & 0 & 0 \\
$3.4 \leq \mathrm{x} \leq 6.7$ & 4 & 36.4 & 12 & 35.3 & 16 & 35.6 \\
$6.8 \leq \mathrm{x} \leq 10$ & 7 & 63.6 & 22 & 64.7 & 29 & 64.4 \\
Total & 11 & 100 & 34 & 100 & 45 & 100 \\
\hline
\end{tabular}

Overall, the mean score that rated by the teachers was observed as 7.28 out of 10 . The details of data for each element are presented in Table 7.

Table 7. Teacher perspectives on actualization of the NEP in private and government secondary school students

\begin{tabular}{llcccccc}
\hline \multirow{2}{*}{ Element of the NEP } & \multicolumn{3}{c}{ Private } & \multicolumn{4}{c}{ Government } \\
& & mean & min & max & mean & min & max \\
\hline 1) & Education is an on-going effort & 6.27 & 3.67 & 7.33 & 6.69 & 3.67 & 9.33 \\
2) & Developing the potential of individual & 6.55 & 4.00 & 8.80 & 7.28 & 3.60 & 9.60 \\
3) & Develop the potential in a holistic and integrated & 6.97 & 4.00 & 8.00 & 7.42 & 4.33 & 9.33 \\
& manner & & & & & & \\
4) & A balanced and harmonious individual & 6.77 & 4.00 & 8.56 & 7.38 & 4.89 & 9.44 \\
5) & Intellectual element & 6.81 & 4.44 & 8.33 & 7.27 & 4.22 & 9.78 \\
6) & Spiritual element & 6.96 & 3.86 & 8.86 & 7.45 & 3.57 & 10.0 \\
7) & Emotional element & 7.23 & 4.33 & 9.00 & 7.22 & 4.67 & 10.0 \\
8) & Physical element & 7.06 & 4.33 & 9.00 & 7.64 & 4.67 & 10.0 \\
9) & Firm belief in and devotion to God & 6.96 & 4.29 & 9.14 & 7.75 & 2.14 & 10.0 \\
10) & Malaysian citizens who are knowledgeable & 6.55 & 3.27 & 8.00 & 6.84 & 2.67 & 10.0 \\
11) & Malaysian citizens who are competent & 6.57 & 3.25 & 8.25 & 7.08 & 4.0 & 10.0 \\
12) & Malaysian citizens who possess high moral & 7.07 & 4.00 & 8.60 & 7.68 & 4.0 & 10.0 \\
& standards & & & & & & \\
13) & Malaysian citizens who are responsible & 6.82 & 5.00 & 8.00 & 7.47 & 4.67 & 10.0 \\
14) & Malaysian citizens who are capable of achieving & 6.79 & 4.00 & 8.00 & 7.45 & 5.00 & 10.0 \\
& a high level of personal well-being & & & & & & \\
15) & Malaysian citizens who are able to contribute to & 6.90 & 4.11 & 8.44 & 7.61 & 5.11 & 10.0 \\
& the betterment of the family, society and the & & & & & & \\
nation & & & & & & \\
\hline
\end{tabular}

With reference to Table 7, the perspective of students on the actualization of the NEP were quite similar, where teachers in both government and private schools proclaimed that the element "Malaysian citizens who possess high moral standards" was one of the top three elements possessed by their students. This perspective was also aligned with student perspectives.

Furthermore, teachers in both private and government schools perceived their students least possessed the elements "Education is an on-going effort" and "Malaysian citizens who are knowledgeable". This perspective was also similar with student perspectives. Teachers perceived their students were lacking in the aspect of "Update himself/herself with the latest knowledge to accommodate with the changes in world" and "love to read". This perspective was coincided with the fact that academic is highly emphasized than other aspects. 


\subsection{Differences between Student and Teacher Perspectives on the Actualization of the NEP}

With reference to Table 8 , the obtained significance value was more than 0.05 , hence failed to reject the null hypothesis 1, with the findings that student and teacher perspectives for the actualization of the NEP in secondary school students did not differ. Therefore, it can be concluded that there was no difference between student and teacher perspectives on the actualization of the NEP in secondary school students. Students perceived themselves to possessing a $76.7 \%$ of the prescribed elements of the NEP. The mean score for teachers was lower than their students; teachers perceived their students possessed $72.8 \%$ of the prescribed elements. Even though there was a gap of knowledge about the NEP between students and teachers, with $97.8 \%$ of the teachers knew the content of the NEP whereas only $15.1 \%$ of students knew the content of the NEP, however, the results for Hypothesis 1 indicated that student perspectives were not affected by the gap. Students' lack of comprehensive understanding of the NEP content could have led to discrepancy in their results pertaining to NEP actualization.

Table 8. Results of independent-sample t-test for teacher and student perspectives

\begin{tabular}{lcccccc}
\hline Actualization of the NEP & $N$ & Mean & $S D$ & $d f$ & $t$ & Sig. \\
\hline Teachers' Perspectives & 45 & 7.28 & 1.24 & 228 & -1.68 & $0.46^{*}$ \\
Students' Perspectives & 185 & 7.67 & 1.43 & & & \\
\hline
\end{tabular}

$* \mathrm{p}<0.05$.

\subsection{Differences between Level of the Actualization for the NEP in Government and Private Secondary School Students}

With reference to Table 9, the obtained significance value was less than 0.05 , hence the null hypothesis 2 was rejected, with the finding that the level of the actualization for the NEP in government secondary school students and the level of actualization for the NEP in private secondary school students did differ significantly. Hence, it can be concluded that there was difference between level of actualization for NEP in government and private secondary school students. The mean score for level of actualization of the NEP in government secondary schools was higher than the mean score in private secondary schools. Given the average score, teachers and students in government schools perceived the level of actualization of the NEP was high $(78.1 \%)$ whereas teachers and students in private schools rated as $70.7 \%$ of actualization.

Table 9. Results of independent-sample t-test for actualization of the NEP in government and private secondary schools

\begin{tabular}{lcccccc}
\hline Level of Actualization in & $N$ & Mean & $S D$ & $d f$ & $t$ & Sig. \\
\hline Government schools & 162 & 7.81 & 1.23 & 228 & 3.80 & $0.01^{*}$ \\
Private schools & 68 & 7.07 & 1.63 & & & \\
\hline$* \mathrm{p}<0.05$. & & & & & &
\end{tabular}

Overall, the major difference prevailed in the results was discrepancy in the actualization of "Firm belief and devotion to God", where students in private secondary schools claimed they least possessed (6.85 out of 10) the element whereas it was most possessed in government secondary schools (8.78 out of 10). Besides, the "Emotional element" was of the highest and third highest as rated by teachers and students respectively in private schools. However, the mean score for "Emotional element" was of fourth lowest and seventh highest as rated by teachers and students in government schools.

\section{Recommendations and Conclusion}

The results indicated the level of actualization of the NEP in secondary schools were reasonably high as rated by the students and teachers respectively. There is still room for improvement. The major absence across the NEP elements was found in "Developing the potential of individual" according to student perspectives and "Education is an on-going effort" with reference to both student and teacher perspectives. Therefore, teachers are 
encouraged to extend their focus on academic holistic development, which also includes other elements of the NEP. This shift of focus requires support from school, parents, community and the Ministry of Education, that they all subscribe to one common goal enshrined by the NEP. Besides, students are encouraged to take initiative to discuss with teachers and parents in order to work out a mutual agreeable program to further develop their potential in a holistic and integrated manner. In order to promote lifelong learning, students can take the initiative to update themselves with the latest knowledge to accommodate with changes in the world. These require facilitation from teachers. However, how these finding reflect the reality need further qualitative in-depth inquiries.

The findings reached the conclusion that students in both government and private secondary schools significantly differ on the level of NEP actualization scale across the sampled schools. This calls for the Ministry of Education to look into organizing NEP related training programs meant especially for teachers in private schools.

Despite the encouraging findings, the limitations of the current study need to be addressed in the scope of future research. This research, first, was confined to private and government secondary schools in Kuching, Sarawak. This means that further studies need to be conducted in other states of Malaysia so as to provide an overall picture on the actualization of the NEP in Malaysia. Second, the questionnaire on the actualization was developed based on the guideline from the Ministry of Education Malaysia, rather than using a standard survey questionnaire. Thus, future studies should validate the factor structure and psychometric properties of the NEP scales.

Given the findings and conclusions, the study suggests that the developers of NEP, the authorities who prepare the curriculum, persons who are implementing the curriculum work together to ensure that the nation is able to achieve the prescribed element of the NEP. The NEP provides the fundamental guideline for the questions of (i) What type of citizen Malaysia wants to produce?, (ii) What type of Malaysia, its citizen would like to live in?, (iii) What values Malaysians would cherish?, and (iv) What are the logical relation between all these? The findings also suggest that the Ministry of Education introduce enhancement workshops for school teachers, especially those in private schools, so that they are better enabled to inculcate NEP across their teaching practices.

\section{References}

Butler, J. D. (1968). Four philosophies and their practice in education and religion (3rd ed.). New York: Harper and Row.

Creswell, W. J. (2012). Educational research: Planning, conducting, and evaluating quantitative and qualitative research (4th ed.). Boston: Pearson Education, Inc.

Fielding, M. (2000). Education policy and the challenge of living philosophy. Journal of Education Policy, 15(4), 377-381. http://dx.doi.org/10.1080/026809300413392

Fowler, F. J. (2009). Survey research methods (4th ed.). Los Angeles, CA: Sage. Cited in Cresswell, W. J. (2012). Educational research: Planning, conducting and evaluating quantitative and qualitative research (4th ed., p. 610). Boston: Pearson Education Inc.

Habsah, I., \& Aminuddin, H. (2009). Holistic education in Malaysia. European Journal of Social Sciences, 9(2), 231-236. Retrieved from http://www.eurojournals.com

Habsah, I., Yunus, A. S. M., Ali, W. Z. W., Hamza, R., Abu, R., \& Nawawi, H. (2009). Belief in God based on the National Education Philosophy amongst Malaysian Secondary School Teachers. European Journal of Social Sciences, 8(1), 160-170. Retrieved from http://www.eurojournals.com/ejss_9_2_05.pdf

Keow, C. (2008). Philosophy and education in Malaysia. Kuala Lumpur: Kumpulan Budiman SDN BHD.

Lee, M. N. N. (1999). Education in Malaysia: Towards vision 2020. School Effectiveness and School Improvement, 10(1), 86-98. http://dx.doi.org/10.1076/sesi.10.1.86.3514.

Lee, S. T., Chia, B. C., \& Nik Hasnaa N. M. (2011). Lifelong learning: Issues of effective Implementation. The International Lifelong Learning Conference (ICLLL) 2011, held from 14-15 November 2011, Seri Pacific Hotel, Kuala Lumpur. Retrieved May 18, 2013, from http://eprints.oum.edu.my/647/

Lewy, A. (1977). Handbook of curriculum evaluation. United States: Unesco.

Lewy, A. (1978). Regional meeting of experts on examination and other procedures for the evaluation of educational achievements and experiments in the Cinctent of Lifelong Education in Europe. Held from 
11-16 December 1978. Paris, Unesco. Retrieved from http://unesdoc.unesco.org/images/0003/000301/030105eb.pdf

Mackenzie, J. S. (1898). The bearings of philosophy on education. International Journal of Ethics, 8(4), 423-438. The University of Chicago Press. Retrieved from http://www.jstor.org/stable/2375587

Meng, E. A. (1996). Pendidkan di Malaysia 1: Falsafah Pendidikan: Guru dan sekolah [Education in Malaysia 1: National Education Philosophy: Teacher and school]. Shah Alam, Malaysia: Penerbit Fajar Bakti Sdn. Bhd.

Ministry of Education Malaysia. (1979). Cabinet report on the study of the implementation of educational policy. Kuala Lumpur.

Ministry of Education Malaysia. (1988). Cabinet report on the study of the implementation of educational policy. Kuala Lumpur.

Ministry of Education Malaysia. (2001). Falsafah Pendidikan Kebangsaan: Matlamat dan misi (National Education Philosophy: Goal and mission). Putrajaya, Malaysia: Curriculum Development Centre.

Ministry of Education Malaysia. (2008). Education in Malaysia: A journey to excellence. Malaysia: Educational Planning and Research Division.

Ministry of Education Malaysia. (2011). Senarai sekolah menengah di Sarawak seperti pada 31 Januari 2011 (List of secondary schools in Sarawak as at 31 January 2011). Retrieved from http://emisportal.moe.gov.my/emis/emis2/emisportal2/doc/fckeditor/File/senarai_sekolah_jan2011/menenga h/SarawakM.pdf

Ministry of Education Malaysia. (2012). The Malaysia education blueprint 2013-2025: Preliminary report. Putrajaya: Kementerian Pelajaran Malaysia.

Mohamed, N. C. (1990). Asas-asas pendidikan: Satu Pengenalan (Basics of education: An introduction). Selangor, Malaysia: Flo Enterprise Sdn. Bhd.

Mohd, N. G., Abdul-Rahim, H., Ahmad-Johari, S., \& Ali, H. (2011). Integrated curriculum concepts in Malaysia: Knowledge and application differentiation. European Journal of Social Sciences, 19(2), 208-217.

Muhamad, S. B. M. A. H. (1993). Sejauh manakah kefahaman dan penghayatan guru sekolah menengah okasional pengkalan chepa terhadap Falsafah Pendidikan Negara (The extent of understanding and appreciation towards National Education Philosophy among teachers in Vokasional Pengkalan Chepa Secondary School) (Thesis. Skudai: Universiti Teknologi Malaysia).

Nooraini, O., \& Khairul, A. M. (2011). Eclectic model in the Malaysian education system, International Education Studies, 4(4), 111-117. http://dx.doi.org/10.5539/ies.v4n4p111

Ornstein, C. A., \& Hunkins, P. F. (2013). Curriculum: Foundations, principles and issues (6th ed.). Boston: Pearson Education, Inc.

Peter, F. O. (1997). Developing the curriculum (4th ed.). United States of America: Pearson Education, Inc.

Rohana, H., Kamarudzaman, M. I., \& Roziah, M. J. (2010). Spiritual education development model. Journal of Islamic and Arabic Education, 2(2), 1-12. Retrieved from http://www.ukm.my/jiae/pdf/16.pdf

Rosnani, H. (2004). Educational dualism in Malaysia: Implications for theory and practice. Kuala Lumpur: The Other Press.

Sang, M. S. (2008). Pengurusan kurikulum (Curriculum management). Selangor, Malaysia: Penerbitan Multimedia Sdn. Bhd.

Santhiram, R. (1997). Curriculum materials for national integration in Malaysia: Match or mismatch? Asia Pacific Journal of Education, 17(2), 7-18. http://dx.doi.org/10.1080/02188799708547758

Teng, S. S. (2008). Persepsi guru terhadap kefahaman dan penghayatan Falsafah Pendidikan Kebangsaan di Skudai, Johor (Perception of teacher towards understanding and appreciation of National Education Philosophy in Skudai, Johor. (Thesis, Skudai: Universiti Teknologi Malaysia).

Wilson, J. (1977). Philosophy and practical education. London: Routledge \& Kegan Paul Ltd. 


\section{Copyrights}

Copyright for this article is retained by the author(s), with first publication rights granted to the journal.

This is an open-access article distributed under the terms and conditions of the Creative Commons Attribution license (http://creativecommons.org/licenses/by/3.0/). 